\title{
PENERAPAN SOFTWARE AKUNTANSI PADA UMKM FEROLAS
}

\author{
SUHARYONO \\ Politeknik Negeri Bengkalis \\ Email: suharyono@polbeng.ac.id
}

\begin{abstract}
Ferolas Preparation of financial reports is a process that should be carried out by every business, including Micro, Small and Medium Enterprises (MSMEs). The information in the financial statements will be useful for owners and stakeholders so that they can monitor and evaluate their business performance and make more informed decisions to improve competitive advantage and business sustainability. Facing the digitalization era in the industrial revolution 4.0 era and using the internet of things (IOT), in carrying out all activities including business and financial reporting, in practice, most MSMEs still need several stages to reach the stage of readiness to adopt advances in information technology in assisting the process. their business. The purpose of this study is to examine the extent to which SMEs understand financial reporting and the extent to which they are prepared to use information technology in financial reporting. The research methodology is a case study on Ferolas SMEs located on Bathin Alam Street, Sungai Alam Village, Bengkalis Riau. Data was collected during April to December 2020 through interviews and observations of financial reporting practices. The results showed that Ferolas had compiled financial reports starting from recording, classifying, summarizing, journalizing with a double entry system and using Ms Excel. However, Ferolas' financial statements are not in accordance with financial accounting standards for Micro, Small and Medium Enterprises (MSMEs) or Financial Accounting Standards for Entities Without Public Accountability (SAK ETAP) and the financial statements have not been presented accurately so that the statement financial statements have not provided optimal use in help assess performance and decision making. This is mainly due to the owner not having sufficient knowledge of financial reporting so that many errors occur in managing transaction evidence, classification, application of accounting methods, and presentation of accounts in financial statements. In addition, Ferolas' financial statements are not verified and not audited by an independent auditor.
\end{abstract}

Keywords: Accounting, MSMEs, SAK, ETAP, Reports.

\begin{abstract}
ABSTRAK
Penyusunan laporan keuangan merupakan proses yang sebaiknya dilakukan oleh setiap usaha, termasuk Usaha Mikro, Kecil dan Menengah (UMKM). Informasi dalam laporan keuangan akan berguna bagi pemilik dan pemangku kepentingan sehingga dapat memantau dan mengevaluasi kinerja bisnis mereka dan membuat keputusan lebih tepat untuk meningkatkan keunggulan kompetitif dan keberlanjutan usaha. Menghadapi era digitalisasi di era revolution industrial 4.0 dan menggunakan internet of things (IOT), dalam menjalankan semua kegiatan termasuk bisnis dan pelaporan keuangan, dalam praktiknya, sebagian besar UMKM masih memerlukan beberapa tahapan untuk sampai pada tahap kesiapan untuk mengadopsi kemajuan teknologi informasi dalam membantu proses bisnis mereka. Tujuan dari penelitian ini adalah untuk mengkaji sejauh mana pemahaman pelaku UMKM pelaporan keuangan dan sejauh mana kesiapan dalam menggunakan teknologi informasi dalam pelaporan keuangan. Metodologi penelitian adalah studi kasus pada UMKM Ferolas berlokasi di Jalan Bathin Alam Desa Sungai Alam Bengkalis Riau. Data dikumpulkan selama bulan April hingga Desember 2020 melalui wawancara dan observasi terhadap praktik pelaporan keuangan. Hasil penelitian menunjukkan bahwa Ferolas telah menyusun laporan keuangan mulai dari pencatatan, mengklasifikasi, meringkas, menjurnal dengan sistem double entry dan menggunakan Ms Excel. Namun, laporan keuangan Ferolas belum sesuai dengan standar akuntansi keuangan untuk Usaha Mikro, Kecil dan Menengah (UMKM) atau Standar Akuntansi Keuangan Entitas Tanpa Akuntabilitas Publik (SAK ETAP) dan laporan keuangan belum disajikan secara akurat sehingga laporan keuangan pernyataan belum memberikan kegunaan yang optimal dalam membantu menilai kinerja dan pengambilan keputusan. Hal ini terutama disebabkan oleh pemilik tidak memiliki pengetahuan yang cukup tentang pelaporan keuangan sehingga banyak terjadi kesalahan dalam mengelola bukti transaksi, klasifikasi, penerapan metode akuntansi, dan penyajian dari akun-akun dalam laporan keuangan. Selain itu, laporan keuangan Ferolas tidak diverifikasi dan tidak diaudit oleh auditor independen.
\end{abstract}

Kata kunci. Akuntansi, UMKM, SAK, ETAP, Laporan.

\section{PENDAHULUAN}

\subsection{Latar Belakang Masalah}

Usaha Mikro Kecil dan Menengah (UMKM) memiliki peran dan kontribusi yang sangat penting bagi perekonomian Indonesia. Menurut data Kementerian Koperasi dan Usaha Kecil Menengah tercatat sejumlah 59,2 juta unit UMKM yang tersebar di seluruh Indonesia. UMKM tercatat telah menciptakan lapangan kerja 96,9\% dari penduduk Indonesia dan berkontribusi 60,3\% terhadap Produk Domestik Bruto (PDB). Oleh karena itu, pemerintah mendukung penuh pertumbuhan UMKM di Indonesia. 
Pemerintah sepakat bahwa UMKM harus dilindungi dan dibantu pertumbuhannya. Hal ini tercermin dari dukungan pemerintah, seperti 1) menyelenggarakan workshop untuk mendorong para pelaku UMKM untuk meningkatkan kompetensinya, 2) membantu penyediaan produk UMKM secara online 3) Standar Akuntansi Keuangan Mikro Kecil dan Menengah Sederhana (SAK EMKM) yang diberikan oleh Dewan Standar Akuntansi Keuangan (DSAK) IAI 4 menyediakan aplikasi software akuntansi gratis seperti Lamikro, Aplikasi Pencatatan Informasi Keuangan (APIK), MYOB, Zahir, dan Accurate. Laporan keuangan UMKM berguna bagi pemerintah untuk mengidentifikasi dan menangani masalah UMKM. Sedangkan bagi UMKM, laporan keuangan berguna untuk mempermudah memperoleh kredit bank. Selain itu, melalui laporan keuangan, UMKM dapat mengetahui biaya produksi, harga jual yang tepat, laba rugi, kewajiban perpajakan, arus kas, dan perkembangan usahanya.

Namun, sebagian besar UMKM (>80\%) masih belum mampu membuat laporan keuangan. Hal ini disebabkan oleh berbagai faktor antara lain 1) tidak memisahkan uang pribadi dengan uang usaha, 2) tidak memiliki modal usaha yang cukup terutama untuk investasi IT, 3) pola pikir bisnis yang menjual, tidak memiliki strategi bisnis sebagai wirausaha, dan 4) pengolahan data belum menjadi kebiasaan untuk membudayakan pencatatan transaksi dan penyusunan laporan keuangan (Widodo, 2021).

Laporan keuangan merupakan kunci keberhasilan UMKM karena penyebab utama kegagalan adalah bisnis. Tanpa sistem pengelolaan keuangan dasar yang baik banyak UMKM yang tidak bertahan lama. Laporan keuangan merupakan kunci keberhasilan UMKM. Tanpa sistem manajemen dan pelaporan keuangan yang memadai, keberlangsungan usaha UMKM menjadi masalah yang sangat penting. Akibat ketidakmampuan penyusunan laporan keuangan, salah satunya UKM dianggap sebagai bisnis yang berisiko tinggi bagi bank.

Penelitian ini menggunakan objek penelitian yaitu perusahaan UMKM dengan tujuan untuk mengetahui pelaporan keuangan pada UMKM. Perusahaan yang akan diteliti oleh penulis adalah Ferolas yang bergerak di bidang pengelasan.

\subsection{Perumusan Masalah}

Berdasarkan judul dan latar belakang yang dikemukakan pada uraian di atas, maka penulis dalam hal ini mengidentifikasi masalah dan sekaligus membatasi masalah yang akan dibahas sebagai berikut:

1. Bagaimana pelaporan keuangan di Ferolas Bengkalis?

2. Bagaimana penerapan dan pengembangan pelaporan keuangan berdasarkan SAK STAP?

3. Bagaimana FEROLAS menghadapi era 4.0?

\section{TINJAUAN PUSTAKA}

Berdasarkan UU No. 20 tahun 2008 bahwa Usaha Mikro, Kecil dan Menengah (UMKM) dikelompokkan berdasarkan besaran modal atau pendapatannya. Usaha mikro adalah usaha yang memiliki kekayaan bersih paling banyak Rp 50.000.000 (lima puluh juta rupiah) tidak termasuk tanah dan tempat usaha atau mempunyai penjualan tahunan paling banyak Rp 300.000.000 (tiga ratus juta rupiah). Usaha Kecil adalah usaha yang memiliki kekayaan bersih lebih dari Rp 50.000.000,00 (lima puluh juta rupiah) sampai dengan paling banyak Rp 500.000.000,00 (lima ratus juta rupiah) tidak termasuk tanah dan bangunan tempat usaha tersebut berada atau mempunyai hasil penjualan tahunan lebih dari Rp 300.000.000,00 (tiga ratus juta rupiah) sampai dengan paling banyak $\mathrm{Rp} 2.500 .000 .000,00$ (dua miliar lima ratus juta rupiah). Usaha Menengah, yaitu usaha yang memiliki aset lebih dari Rp 500.000.000,00 sampai dengan paling banyak Rp 10.000.000.000,00 (sepuluh miliar rupiah) tidak termasuk tanah dan bangunan tempat usaha berada atau memiliki penjualan lebih dari $\mathrm{Rp} 2.500 .00 .000,00$ (dua miliar lima ratus juta rupiah) sampai dengan paling banyak Rp 50.000.000.000,00 (lima puluh miliar rupiah)

Penelitian Arisinta (2019) menyimpulkan bahwa sebagian besar UMKM sudah menerapkan pencatatan dan pelaporan akuntansi pada usaha yang dimiliki. Transaksi yang paling banyak dicatat adalah transaksi penjualan $(80 \%)$, pembelian $(80 \%)$, kas masuk $(70 \%)$ dan kas keluar $(70 \%)$. Namun hal ini belum terjadi pada pembuatan buku besar, hal ini dibuktikan dengan hanya $20 \%$ responden melakukan pengelompokan akun-akun ke dalam buku besar dengan sebagian besar alasan tidak membuat buku besar karena merasa tidak perlu membuatnya (80\%).

Dalam penelitian eksplorasi yang dilakukan Raharja (2018) tentang keberhasilan paket perangkat lunak dalam usaha kecil berpendapat bahwa usaha kecil sering kecewa dengan paket perangkat lunak mereka karena sulit digunakan (untuk bisnis dengan kurang dari 20 karyawan) atau tidak memenuhi kebutuhan perusahaan (dalam bisnis dengan lebih dari 50 karyawan). Berdasarkan penelitian eksplorasi kami, kami percaya bahwa ini mungkin tidak valid lagi dengan perangkat lunak usaha kecil yang tersedia saat ini dimana kesimpulan ini diambil dengan menggunakan ukuran sampel yang kecil.

Dalam bisnis kecil, untuk pelaporan keuangan secara manual, biasanya hanya dua orang yang mengelola akuntansi, yaitu pemilik dan seorang akuntan/kasir. Pekerjaan yang terlibat dan biaya yang terkait dalam melakukan pembukuan jelas dan tidak ada ketidakpastian atau risiko bagi pemilik. Jika pembukuan secara komputerisasi dengan menggunakan software berbasis DOS, jumlah orang yang terlibat dalam pengelolaan akuntansi bertambah menjadi tiga orang atau lebih, yaitu pemilik, akuntan, staf IT dan beberapa karyawan. Tidak ada pembaruan otomatis pada perangkat lunak ini, kecuali jika diminta oleh pemiliknya. 
Biaya awal biasanya tinggi, sedangkan dengan paket perangkat lunak yang tersedia saat ini dengan manfaat seperti keterjangkauan dan fungsionalitas tinggi datang bersamaan dengan potensi kompleksitas, risiko, ketidakpastian, dan ketergantungan. Misalnya, pemilik sekarang bergantung pada beberapa ahli, seperti: akuntan, konsultan perangkat lunak, konsultan TI, dan karyawan terlatih TI/perangkat lunak. Biaya koordinasi untuk pemilik usaha kecil meningkat dan risiko kesalahan dalam memelihara dan menggunakan perangkat lunak akuntansi juga meningkat (Pulakanam, 2010). Peningkatan kompleksitas rantai pasokan yang terkait dengan penerapan perangkat lunak akuntansi digambarkan pada gambar 2.1.

\section{Gambar 2.1}

Perbandingan Antara Akuntansi Manual, Software Berbasis DOS, dan Packaged Software

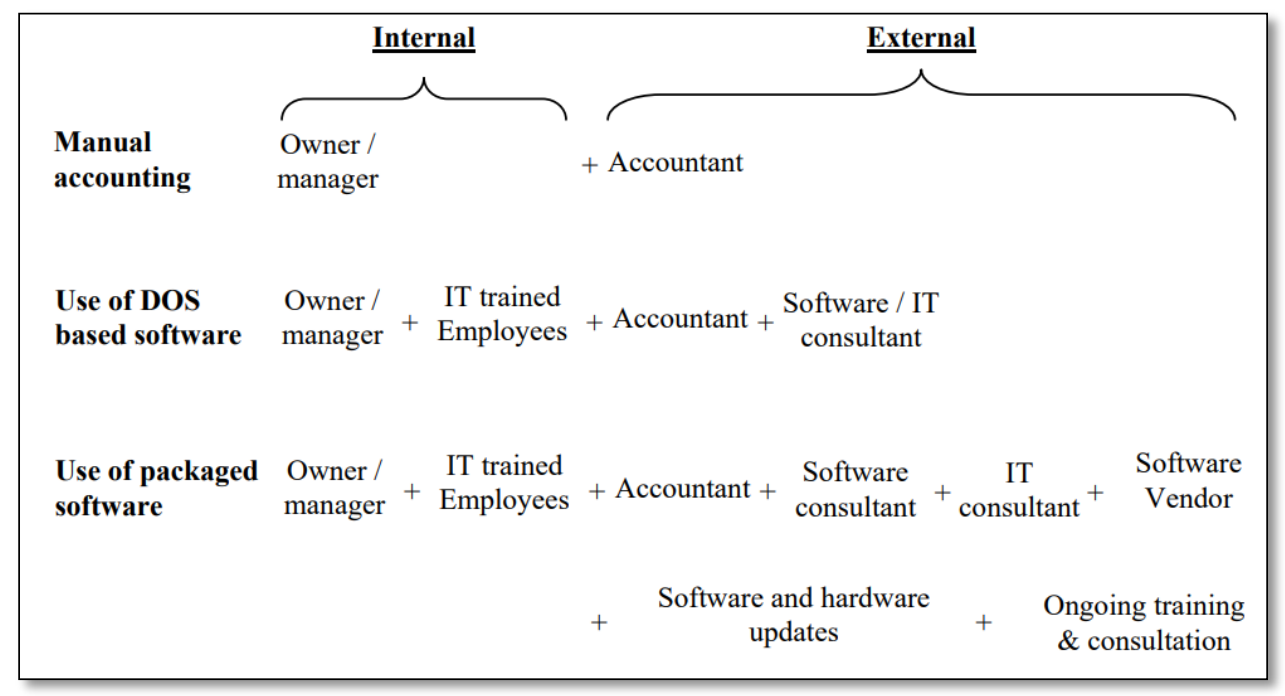

Sumber: Pulakanam (2010)

Akuntansi adalah suatu sistem dengan input data/informasi dan output berupa informasi keuangan dan laporan yang berguna bagi pengguna internal dan eksternal entitas. Siklus Akuntansi meliputi identifikasi transaksi, pencatatan jurnal, buku besar, penyusunan neraca, pencatatan ayat jurnal penyesuaian, penyusunan neraca, penyusunan laporan keuangan, pencatatan jurnal penutup, dan pencatatan jurnal pembalik. Beberapa bisnis menggunakan sistem akuntansi terkomputerisasi. Agar tetap kompetitif, perusahaan terus meningkatkan sistem akuntansi mereka untuk menyediakan data yang akurat dan tepat waktu untuk pengambilan keputusan.

Menurut Romney \& Steinbart (2018), akuntansi adalah sebuah sistem informasi, pengetahuan, dan keterampilan sistem informasi akuntansi (SIA) sangat penting untuk keberhasilan karir seorang akuntan. Berinteraksi dengan SIA adalah salah satu kegiatan terpenting yang dilakukan akuntan. American Institute of Certified Public Accountants (AICPA) menawarkan CITP (Certified Information Technology Professional) sebagai pengakuan akan pentingnya TI dan relevansinya dengan akuntansi.

Perangkat lunak akuntansi, yang berada di bawah definisi luas Akuntansi Sistem Informasi (SIA), adalah perangkat lunak komputer yang merekam dan memproses transaksi akuntansi dalam modul fungsional seperti hutang, piutang, penggajian, dan neraca saldo. Ini dapat dikembangkan di rumah oleh organisasi yang menggunakannya, dapat dibeli dari pihak ketiga (dikemas siap pakai) perangkat lunak seperti Lamikro, APIK, Zahir, Accurate, dan MYOB, atau mungkin kombinasi dari pihak ketiga paket perangkat lunak aplikasi dengan modifikasi lokal. Ini sangat bervariasi dalam kompleksitas dan biaya. Perangkat lunak akuntansi paket hari ini tidak hanya mencatat transaksi keuangan dan menghasilkan laporan akuntansi, tetapi mencakup fungsionalitas untuk pengambilan keputusan manajerial yang bertujuan untuk mendapatkan keunggulan kompetitif (Suharyono, 2019).

Menurut kepada Zamzami (2021), perangkat lunak akuntansi bisnis kecil telah membuat lompatan teknologi dalam kekuatan, kecepatan, kecanggihan, dan fleksibilitas dalam beberapa tahun terakhir. Mahardika (2019) mencatat bahwa selama bertahun-tahun, pemasok perangkat lunak telah menambahkan lebih banyak fitur inovatif untuk paket keuangan mereka, seperti antarmuka web dan yang lebih baik integrasi dengan rantai pasokan dan aplikasi lain, dan mereka juga telah berubah produk untuk membuatnya lebih berguna bagi nonakuntan.

Menurut Ikatan Akuntan Indonesia (IAI) (2015) dalam Pernyataan Standar Akuntansi Keuangan No. 1 laporan keuangan adalah penyajian terstruktur dari posisi keuangan dan kinerja keuangan suatu entitas. Laporan keuangan terdiri dari laporan laba rugi, laporan posisi keuangan, laporan perubahan ekuitas, laporan arus kas, dan catatan atas laporan keuangan. Sedangkan akuntansi komputer merupakan terobosan bagi perkembangan teknologi, informasi, dan komunikasi yang berkaitan dengan proses akuntansi perusahaan. Komputer akuntansi dimaksudkan untuk memberikan kemudahan dalam menyusun laporan keuangan perusahaan dengan lebih cepat, akurat, dan tidak memerlukan banyak waktu. 


\section{METODOLOGI PENELITIAN}

Penelitian yang dilakukan menggunakan metode studi kasus. Studi kasus digunakan untuk menganalisis dan memecahkan sebuah permasalahan dalam praktek bisnis. Seperti yang dijelaskan oleh Raco (2018) studi kasus memiliki peran penting dalam sebuah penelitian bisnis. Strategi penelitian studi kasus dapat digunakan untuk menganalisis dan memecahkan masalah bisnis praktis, serta untuk membangun dan menguji teori bisnis. Studi kasus adalah penyelidikan empiris yang menyelidiki fenomena kontemporer dalam konteks kehidupan nyata, terutama ketika batas-batas antara objek studi dan konteks tidak jelas. Studi kasus adalah studi satu kasus (studi kasus tunggal) atau sejumlah kecil kasus (studi kasus komparatif) dalam konteks kehidupan nyata dipilih dan skor yang diperoleh dari kasus-kasus tersebut dianalisis dalam unit kualitatif.Untuk menjawab masalah yang telah diidentifikasi.

Sumber data yang digunakan adalah data primer yang merupakan data yang langsung diperoleh dari sumber data pertama di lokasi penelitian atau objek penelitian. Selain itu penelitian ini juga menggunakan data sekunder yang diperoleh dari catatan mutasi data keuangan. Data untuk penelitian ini dikumpulkan dari sebuah kasus di perusahaan UMKM yaitu Ferolas yang terletak di Jalan Bathin Alam Desa Sungai Alam Bengkalis Riau. Teknik pengumpulan data menggunakan observasi, wawancara, dan dokumentasi. Teknik analisis data meliputi tahapan reduksi data, penyajian data, dan penarikan kesimpulan serta verivikasi.

\section{HASIL PENELITIAN DAN PEMBAHASAN}

\subsection{Hasil Penelitian}

Ferolas telah menyusun laporan keuangan dimana dalam penyusunan laporan keuangan, perusahaan telah menggunakan sistem pembukuan ganda. Meski demikian, Ferolas hanya membuat laporan laba rugi. Laporan laba rugi yang dibuat oleh perusahaan ini masih memiliki banyak kesalahan yaitu laporan laba rugi hanya mencakup item pendapatan, beban keuangan, dan beban pajak dan laporan laba rugi tidak menampilkan pengeluaran yang terkait dengan aset tetap. Pembelian peralatan dicatat sebagai beban tetapi pada akhir periode tidak dilakukan penyesuaian terhadap saldo peralatan yang tersisa. Selain itu, terdapat beban pembelian yang ditempatkan dalam beban usaha sedangkan biaya tercatat pembelian merupakan komponen dari harga pokok penjualan. Kesalahan juga terjadi dalam penjurnalan biaya yang masih harus dibayar. Perusahaan tidak menyesuaikan beban utangnya, seperti utang beban utilitas, utang gaji, dan utang BPJS. Beban utilitas yang ditampilkan dalam laporan menunjukkan beban yang seharusnya dibebankan pada periode sebelumnya.

\subsection{Pembahasan}

Dalam menghitung persediaan, perusahaan tidak dapat mengetahui metode yang digunakan. Perusahaan hanya melakukan stock opname kemudian jumlah barang tersebut dikalikan dengan perkiraan harga. Perusahaan juga tidak melakukan penyusutan aset tetap dimana menurut informasi yang diterima peneliti, staf akuntansi mengalami kesulitan dalam mengidentifikasi aset tetap perusahaan dan menentukan masa manfaat aset tersebut. Oleh karena itu, staf akuntansi tidak menyusutkan asset karena laporan keuangan yang dapat dilaporkan hanya berupa laporan laba rugi, maka staf akuntansi mengalami kesulitan dalam menyampaikan informasi keuangan kepada pemilik entitas. Hal ini tentunya akan mempengaruhi pengambilan keputusan untuk investasi, operasional, dan estimasi.

Pemahaman tentang software akuntansi sangat penting dalam proses penerapan akun ke laporan keuangan perusahaan. Pemahaman ini juga harus dikembangkan lebih lanjut dalam memenuhi proses pelaporan yang lebih mudah dan otomatis. Menu awal atau tampilan awal dimaksudkan untuk input data-data yang akan diulang pada lembar sesudahnya atau ringkasan dari keseluruhan dokumen di software. Hal ini dimaksudkan untuk meminimalkan tingkat akuntabilitas dan efektifitas input sebuah data. Menu awal dapat mencantumkan nama perusahaan, tanggal periode laporan, ringkasan proses akuntansi, dan sebagainya.

Proses akuntansi yang menghasilkan laporan keuangan dalam proses penyusunan yang terkomputerisasi tidak melalui semua tahapan proses akuntansi manual tetapi diproses secara otomatis. Pengisian data meliputi nama perusahaan, tanggal periode pembukuan, dan daftar rekening sesuai kebutuhan perusahaan. Langkah terakhir adalah memasukkan data rinci dari akun seperti nomor akun, nama akun, jenis akun, akun induk untuk akun selain header akun, informasi untuk akun kontra, dan saldo normal setiap akun. Akun telah diklasifikasikan ke dalam aset, kewajiban, ekuitas, pendapatan, dan beban.

Peneliti memperoleh sebagian data dari perusahaan dan akun-akun terpilih yang mencerminkan keadaan yang sebenarnya. Pengukuran dan klasifikasi aset dilakukan sesuai dengan ketentuan klasifikasi aset lancar dan memisahkan aset tidak lancar yang tidak sesuai dengan klasifikasi aset tersebut (Indonesia, 2019). Data yang diperoleh sesuai dengan ketentuan adalah data kas, piutang, biaya dibayar dimuka, dan pelengkapan. Sedangkan untuk peralatan, peneliti mengolah data dari awal dengan melakukan perhitungan fisik dan penetapan harga dengan harga pada kondisi harga pasar. Peneliti juga menghitung kembali akumulasi penyusutan dengan bantuan tabel peralatan. Sedangkan untuk akun kewajiban dan ekuitas, peneliti hanya menambahkan saldo untuk mengakui beban yang masih harus dibayar dan utang pajak penghasilan.

Jurnal umum dicatat secara sistematis dan entri sistem ganda. Transaksi yang terjadi di Ferolas meliputi transaksi penjualan tunai, pembelian/pengiriman bahan baku, pembayaran gaji, pembayaran hutang dagang, dan pembayaran beban operasional perusahaan. Buku besar disusun secara otomatis dengan bantuan rumus. Buku besar menampilkan saldo akhir dan mutasi dari setiap saldo akun dimana saldo yang ditampilkan akan dimasukkan dalam laporan keuangan. Jurnal penyesuaian yang dilakukan meliputi 
penyesuaian akrual untuk gaji, utilitas, pajak dan iklan, penyesuaian sewa dibayar di muka, penyusutan peralatan, amortisasi biaya pendirian, iklan dibayar di muka, serta penyesuaian persediaan.

Laporan laba rugi disusun sesuai dengan pedoman SAK ETAP. komponen laporan keuangan meliputi pendapatan dan beban. Laporan posisi keuangan telah sesuai dengan ketentuan dalam SAK ETAP. Seperti dijelaskan sebelumnya, laporan posisi keuangan harus mencakup kas, piutang, persediaan, aset tetap, utang usaha, dan ekuitas. Ferolas menyajikan pos aset berdasarkan urutan likuiditas dan utang berdasarkan jatuh tempo.

Dalam penelitian penerapan perangkat lunak akuntansi di UMKM, tidak ada kegagalan besar yang dilaporkan, meskipun masalah kecil tertentu diidentifikasi terutama pada tahap awal penggunaan sistem setelah instalasi. Pemilik bisnis melaporkan bahwa mereka umumnya senang dengan sistem yang telah diterapkan. Dalam beberapa kasus, kinerjanya jauh melebihi harapan mereka.

Melihat industri perangkat lunak dari mata UMKM, pemilik UMKM kewalahan dengan pilihan dan informasi. Memutuskan software akuntansi mana yang akan dipilih lebih rumit dan mungkin memiliki efek negatif pada keputusan pemilik. UMKM seringkali tidak dalam posisi untuk mengevaluasi secara objektif apakah mereka membutuhkan perangkat lunak akuntansi dan jika perangkat lunak mana yang harus mereka peroleh dan bagaimana hal itu dapat diimplementasikan. Tidak seperti bisnis yang lebih besar, UMKM mendapat manfaat dari saran independen tentang pemilihan dan implementasi perangkat lunak akuntansi. Kurangnya saran independen seperti itu meningkatkan risiko pemilihan perangkat lunak yang salah, peningkatan biaya dan kegagalan implementasi dan dapat menjadi penghalang untuk penggunaan TI dalam UMKM.

Pemasangan versi dasar perangkat lunak dan termasuk pelatihan sangat mudah dan memakan waktu sekitar sepuluh jam. Masalah jarang terjadi dengan implementasi seperti itu. Konsultan memberikan dukungan berkelanjutan, yang persyaratannya minimal dengan penerapan modul dasar. Untuk implementasi versi lanjutan dari perangkat lunak, keahlian dan pengalaman konsultan perangkat lunak eksternal sangat penting untuk keberhasilan implementasi. Selain pengetahuan akuntansi dan perangkat lunak, mereka perlu memiliki keterampilan analisis bisnis dan keterampilan pembinaan. Dengan penerapan modul lanjutan, mereka harus pandai menyesuaikan instalasi perangkat lunak, memberikan pelatihan dan berkomitmen untuk memberikan dukungan berkelanjutan. Bantuan konsultan eksternal hampir selalu diperlukan dalam kasus ini untuk membuat perubahan pada perhitungan dalam modul penggajian perangkat lunak.

\section{KESIMPULAN DAN SARAN}

\subsection{Kesimpulan}

Penelitian tentang pelaporan keuangan bagi UMKM di era revolusi industri 4.0, studi kasus pada Ferolas, memberikan hasil sebagai berikut:

1. Ferolas telah menggunakan Ms. Excel untuk pelaporan keuangan namun belum sesuai dengan SAK EMKM. Laporan yang dihasilkan hanya laporan laba rugi. Laporan laba rugi yang dihasilkan tidak hanya menampilkan pendapatan, pengeluaran, dan pajak, tetapi pengeluaran untuk pembelian aset dan pembayaran utang ditampilkan;

2. Ferolas belum memiliki SDM yang memadai untuk menggunakan Ms. Excel secara optimal dan menyusun laporan keuangan yang sesuai dengan SAK EMKM, sehingga timbul kesalahan dalam pelaporan keuangan. Kesalahan yang terjadi berupa kesalahan pengakuan (akrual) pendapatan dan beban baik nominal maupun waktu; dan

3. Ferolas masih memiliki pola pikir sebagai pedagang, bukan sebagai pengusaha, sehingga belum memiliki strategi bisnis jangka panjang, sehingga belum mengantisipasi tantangan dan peluang bisnis di era revolusi industri 4.0

\subsection{Saran}

Berdasarkan kesimpulan yang telah dijelaskan, penulis menyarankan untuk pengembangan perusahaan sebagai berikut:

1. Ferolas perlu membudayakan atau memiliki kebiasaan dalam mencatat transaksi keuangan dan pelaporan sehingga kelangsungan usaha dalam jangka panjang. Ini termasuk memproses bukti transaksi, mengidentifikasi dokumen transaksi, mencatat, mengelola dokumen, dan mengarsipkan dokumen

2. Ferolas wajib mempekerjakan atau mempekerjakan akuntan yang memiliki keterampilan pelaporan keuangan berbasis sistem informasi dan teknologi informasi

3. Sebelum beralih ke software akuntansi yang lebih kompleks, Ferolas membutuhkan pemahaman tahap demi tahap aplikasi akuntansi dan pelaporan keuangan berbasis komputer. Ferolas harus mulai memahami dari sistem akuntansi yang sederhana untuk dapat menerapkan sistem akuntansi yang lebih kompleks di era digital ini. 


\section{DAFTAR PUSTAKA}

Arisinta, O. 2019. Penerapan Pencatatan Dan Pelaporan Akuntansi Pada Usaha Mikro Kecil Dan Menengah (UMKM) Kecamatan Kamal Kabupaten Bangkalan. Eco-Socio: Jurnal ilmu dan Pendidikan Ekonomi, 3(1), 9-16.

Indonesia, I. A. 2009. Standar akuntansi keuangan entitas tanpa akuntabilitas publik.

Ikatan Akuntan Indonesia. 2015. Pernyataan Standar Akuntansi Keuangan. Jakarta : Ikatan Akuntan Indonesia.

Mahardika, A. G., Pramiudi, U., \& Fahmi, A. 2019. Peranan Penerapan Sistem Akuntansi Accurate Terhadap Penyusunan Laporan Keuangan (Studi Kasus Pada Umkm Toko Textile Leuwi Di Bogor). Jurnal Ilmiah Akuntansi Kesatuan, 7(1), 193-196.

Pulakanam, V., \& Suraweera, T. 2010. Implementing accounting software in small business in New Zealand: an exploratory investigation. Accountancy Business and the Public Interest, 9(64), 98-124.

Rahardja, U., Aini, Q., \& Hardini, M. 2018. Penerapan Software Akuntansi Online Sebagai Penunjang Pencatatan Laporan Keuangan. Sisfotenika, 8(2), 176-187.

Raco, J. 2018. Metode penelitian kualitatif: jenis, karakteristik dan keunggulannya.

Romney, M. B., \& Steinbart, P. J. 2018. Accounting Information Systems (14th ed.). Pearson Education

Suharyono, S. 2019. The Effect Of Accountability, Transparency, And Supervision On Budget Performance By Using The Concept Of Value For Money In Regional Business Enterprises (Bumd) Of Riau Province. International Journal of Public Finance, 4(2), 236-249.

Widodo, T., \& Suharyono, S. 2021. Pengaruh Perencanaan Serta Pelaksanaan Dan Penatausahaan Terhadap Pertanggungjawaban Keuangan BUMDESA di Kabupaten Bengkalis. At-Tadbir: jurnal ilmiah manajemen, 5(1), 35-46.

Zamzami, F., Nusa, N. D., \& Faiz, I. A. 2021. Sistem Informasi Akuntansi. UGM PRESS.

Undang-Undang Republik Indonesia Nomor 20 Tahun 2008 Tentang Usaha Mikro, Kecil, dan Menengah. Jakarta. 